\title{
Mud Bricks in a Concrete State:
}

\section{Building, Maintaining and Improving One's Own House}

in Soviet Samarkand, 1957-1991

\section{Jonas van der Straeten and Mariya Petrova}

In 1963, the journal Building and Architecture in Uzbekistan printed an arranged photo of four urban planners engaged in an animated conversation about an architectural model in front of them. ${ }^{1}$ This model displayed the prospective city centre of Samarkand after its socialist transformation. In the model, the city's old Islamic neighbourhoods had been entirely demolished and replaced by multistorey, prefabricated residential buildings that lined roads radiating from the historical Registan complex. These neighbourhoods of the Old City, known as mahallas, had long been a thorn in the side of Soviet planners - symbolically and materially the narrow alleyways and mud-brick houses stood in the way of the city's modernisation. Now, after having barely changed in appearance for several hundred years - throughout half a century of Russian colonial administration and thirty years of Soviet Stalinist rule - the mahallas were set to finally give way to the rational urban planning of the Khrushchev era. This model of the new city centre, however, never became reality, owing to resource constraints and controversies over the final concept for its reconstruction. ${ }^{2}$ Ultimately, the $m a-$ hallas would even survive the mass housing campaign that started in the late 1950s. The overall vision of an all-out modernisation of Samarkand remained confined to a handful of micro-districts (mikrorayons) on the outskirts of the city. Until the collapse of the Soviet Union and beyond, Samarkand would large-

1 Printed in Stroitel'stvo i arhitektura Uzbekistana, 01 (1964), p. 34.

2 Central State Archive of the Republic of Uzbekistan/Tsentral'nyj Gosudarstvennyj arkhiv Respubliki Uzbekistan (TsGARUz), f. 2532 (Architects' Union of the Uzbek SSR/Sojuz Arkhitektorov UzSSR), op. 2, d. 21, 11. 61-72. 
ly remain a city of adobe bricks, with prefabricated concrete apartment blocks at its fringes only.

By and large, research on Soviet cities has focused on change and the transformative power of socialist urban development. ${ }^{3}$ By looking at the Soviet modernisation project in Central Asia through the prism of Samarkand, a second-tier city in the Uzbek SSR, our chapter draws attention to a degree of (ethno)cultural and material persistence in the cityscape that seems surprisingly high, given the Soviet Union's own aspirations regarding urban modernisation. Cultural and material persistence, we argue, cannot be regarded independently of each other. On the one hand, the courtyard house as a type of urban housing that is widespread in the cities of Central Asian oases embodies local (ethno)cultural norms and conventions associated with the social production of space. ${ }^{4}$ Adobe brick architecture proved to be well suited to address these requirements for space-making and hence persisted as the dominant technology for the maintenance and renovation of family houses, especially in light of a general scarcity of industrially manufactured construction materials. On the other hand, the inherent characteristics of this millennia-old technology, its intensiveness in terms of labour and maintenance, demanded recurrent collective activities of rebuilding and renovating. The culture of collective self-help that was a precondition for "individual house construction" (Individual'noye stroitel'stvo) did not only serve a functional purpose. ${ }^{5}$ For some local ethnic groups it can be interpreted as an important

3 See Kotkin, Stephen: Magnetic Mountain. Stalinism as a Civilization, Berkeley: University of California Press 1997; Stronski, Paul: Tashkent. Forging a Soviet City, 1930-1966, Pittsburgh: University of Pittsburgh Press 2010.

4 Ethnic designations are a particularly intricate issue, yet they remain an important heuristic. In our text, for example when referring to Tajiks, Uzbeks and Bukharian Jews as dwellers of the Old City in Samarkand, we use designations that correspond to the (context-specific) self-attribution of our respondents (or their voices in the archives). When doing so, we are well aware of the historical complexity of the linguistic and ethnic landscape in Central Asia in general and in Samarkand in particular, as well as the fact that existing ethnic categories were defined and enforced by the Soviet administration as part of the national delimitation politics. For an in-depth discussion see: Hirsh, Francine: Empire of Nations. Ethnographic Knowledge and the Making of the Soviet Union, Ithaca: Cornell University Press 2005; Suny, Ronald Grigor/Martin, Terry (eds.): A State of Nations. Empire and Nation-Making in the Age of Lenin and Stalin, New York: Oxford University Press 2001.

5 "Individual house construction" is an official Soviet term, based on the legal division between "private" and "individual" property, whereby the former was a "capitalist" form of property, used for generating private profit, and the latter was conceptualised 
act of cultural self-affirmation - not least through the reference to hashar, a tradition of neighbourhood help deeply engrained in narratives about Central Asian traditional heritage and cultural identity.

Following Stephen Kotkin's call to "[shift] the focus from what the party and its program prevented to what they made possible, intentionally and unintentionally", we therefore offer a perspective on the fragmentary nature of the Soviet urban modernisation process in Central Asia that focuses on the frameworks of individual action. ${ }^{6}$ The persistence of privately built adobe brick houses in Samarkand, we argue, does not simply mirror the deficiencies of the Soviet shortage economy and the limitations of Soviet urban development. By applying elaborate strategies of self-help and labour mobilisation in construction, the residents of Samarkand maintained considerable agency not only in shaping their material environments but also in preserving "traditional" (and hence pre-Soviet) cultural identities.

Our analysis draws on in-depth oral history interviews with owners of houses and apartments in a variety of neighbourhoods and their corresponding modes of housing in Samarkand. ${ }^{7}$ These are complemented by archival research in the City Archive of Samarkand and the Central State Archive in Tashkent as well as a review of contemporary Soviet literature on construction and architecture in Central Asia, for example the journal Building and Architecture in Uzbekistan

as property for personal use only and therefore as legitimate in a socialist society. See Smith, Mark B.: Property of Communists. The Urban Housing Program from Stalin to Khrushchev, DeKalb: Northern Illinois University Press 2010, p. 143. When referring to the practice of building one's own house (usually a free-standing one-family house) for personal use - especially in the context of the Soviet legal system -, we therefore use the term individual house building in our chapter. For the sake of readability, we replace this expression with more commonly used terms like "privately owned houses" and "self-help construction" when the legal context is not of relevance.

6 Kotkin, Magnetic Mountain, p. 22 (italics original).

7 For our study, we conducted a total of ten in-depth oral history interviews with residents living in different neighbourhoods of Samarkand. Our qualitative approach does not, of course, provide for statistical representativeness and extrapolation to all strata of urban society. Yet while being aware of the pitfalls of oral history, such as skewed and incomplete memory, we were surprised by the congruousness and consistency of responses regarding self-help building and its cultural interpretations. Our educated guess is that mundane practices of house building leave traces in memory that are less blurred by shared narratives than, say, the impacts of political events. Moreover, most of our interviews took place within the very houses that were the subject of interest, and through their very materiality they served as a handy memory aid. 
(Stroitel'stvo i arkhitektura Uzbekistana). ${ }^{8}$ The chapter focuses on the last three decades of Soviet rule in Uzbekistan, between 1957, the year that marked the shift from a rather reactive housing policy to a proactive policy under Khrushchev, and the year 1991, the end of the Soviet Union and its economic and legal framework for housing construction.

\section{BUILDING AND IMPROVING HOMES IN LATE SOVIET SAMARKAND: FRAMEWORKS OF INTERPRETATION}

Our micro-study on the persistence of adobe brick houses in Samarkand and the people building, maintaining and improving these houses connects with a debate that revolves around the question of continuity and persistence in the process of Central Asia's Sovietisation. In historical research on technology and material culture, a field that has long been preoccupied with change and novelty, continuity and persistence are two analytical categories scholars have barely made use of. ${ }^{9}$ Research on Central Asia is no exception. The little attention the region has received regarding its history of technology has been almost exclusively focused on the transformation of societies and environments brought about by the transfer of large-scale technologies under Tsarist Russia, and later under Soviet rule. Matthew Payne has described the Turksib railroad in terms of a grand social engineering project, the "forge of the Kazakh proletariat" to transform nomads into an industrial working class. ${ }^{10}$ In the tradition of James Scott, an extensive body of literature has investigated the large-scale irrigation schemes that turned the

8 Uzbek archives, although difficult to access for foreign researchers, are generally well organised and hold a wealth of information left by a Soviet administration almost obsessed with written documentation. The voices of private house owners and house builders can be traced especially well through documentation left by the lowest level of state administration (e.g. neighbourhood committees) or the widespread practice of writing petition letters.

9 Edgerton, David: The Shock of the Old. Technology and Global History since 1900, London: Profile Books 2006. For an overview see Krebs, Stefan/Schabacher, Gabriele/Weber, Heike (eds.): Kulturen des Reparierens: Dinge - Wissen - Praktiken, Bielefeld: transcript 2018.

10 Payne, Matthew J.: Stalin's Railroad. Turksib and the Building of Socialism, Pittsburgh: University of Pittsburgh Press 2001. 
Central Asian steppe into one of the biggest cotton-growing areas of the world and examined these schemes' disastrous environmental (and social) impacts. ${ }^{11}$

According to the narrative underlying most studies, Soviet rule in Central Asia profoundly reconfigured every aspect of the material foundation of state, sociality and everyday life. ${ }^{12}$ In this narrative, Central Asians only appear as actors once they have been incorporated into the Soviet state economy as workers, technicians and later also engineers or specialists - especially in the two postWorld War II decades, when the first generation of Central Asians had passed through the Soviet higher education system. What these studies largely ignore, however, is the persistence of technologies that are termed "local" or "traditional" and their interaction with the Soviet project. The mundane realm of local house building, we argue, is fertile ground to which the analytical lens of persistence and continuity in the Sovietisation of Central Asia can be applied.

While still prevalent in the field of technology, the interpretation of Soviet rule as a top-down modernisation process has been questioned and differentiated in historical research on topics such as religion, gender or the formation of a Central Asian Soviet intelligentsia. ${ }^{13}$ While the Stalinist period has been extensively studied and arguably considerably shaped the image of Soviet Central Asia, the period after Khrushchev's accession to power, when the Soviet Union showed its more humane face, has attracted much less attention. A laudable ex-

11 See for example Obertreis, Julia: Imperial Desert Dreams: Cotton Growing and Irrigation in Central Asia, 1860-1991, Göttingen: V\&R Unipress 2017.

12 Van der Straeten, Jonas: "Borderlands of Modernity. Explorations into the History of Technology in Central Asia, 1850-2000”, in: Technology and Culture 60, 3 (2019), p. 659-687.

13 Roberts, Flora: Old Elites under Communism. Soviet Rule in Leninobod, $\mathrm{PhD}$ thesis, University of Chicago 2016, p. 19; see also Khalid, Adeeb: Making Uzbekistan. Nation, Empire, and Revolution in the Early USSR, Ithaca: Cornell University Press 2015; Khalid, Adeeb: Islam after Communism. Religion and Politics in Central Asia, Berkeley: University of California Press 2007; Northrop, Douglas: Veiled Empire. Gender and Power in Stalinist Central Asia, Ithaca: Cornell University Press 2004; Kamp, Marianne: The New Woman in Uzbekistan. Islam, Modernity, and Unveiling Under Communism, Seattle: University of Washington Press 2006; Kalinovsky, Artemy: Laboratory of Socialist Development. Cold War Politics and Decolonization in Soviet Tajikistan. Ithaca: Cornell University Press 2018; Stronski, Tashkent; Florin, Moritz: Kirgistan und die sowjetische Moderne: 1941-1991, Göttingen: V\&R Unipress 2015. Florin analyses public and elite discourses in Kyrgyzstan, showing the inner-republic perspective on important historical, political and cultural events and processes in Soviet post-war history. 
ception is Sergey Abashin's book Soviet Kishlak, a historical ethnography of one village in northern Tajikistan, which is highly instructive for getting beyond the established dichotomies of "tradition" versus "modernity", "resistance" versus "accommodation" - not least because the author is one of the few to transcend the boundary between Soviet and Western scholarship. ${ }^{14}$ Abashin pays particular attention to the complexity of the often contradictory relationship between the Soviet state and its citizens. While certain Soviet practices became part of the daily life of villagers, he shows, they coexisted and overlapped with other practices that were considered "Muslim", "national" or "traditional". Most kolkhoz members, for example, worked on collective lands only occasionally and dedicated most of their time to other activities such as animal husbandry or handicrafts. We follow Abashin's suggestion to conceptualise local people's living environment as a "mosaic, consisting of multiple sub-spaces", not only for rural Tajikistan but also for Samarkand. ${ }^{15}$ While Abashin is primarily interested in social spaces, we look at the material implications of this fragmentation and the agency of individual people in shaping materiality within different sub-spaces. ${ }^{16}$

Housing appears as a specific field of study in this regard. On the one hand, it was an area of state intervention that saw the most ambitious (and arguably successful) political programmes, in particular the mass housing programme under Khrushchev starting in the late 1950s, and the most far-reaching social engineering visions of changing people's daily lives and material conditions. On the other hand, it was one of the policy areas in which the state administration was arguably most reflective about its limitations in terms of resources and institutional efficiency and allowed for a relatively high degree of permitted autonomy and individual ownership. ${ }^{17}$ It is no irony that Stephen Kotkin's widely cited call to study the agency of individuals within Soviet society is taken from a book on what was arguably one the Soviet Union's most radical urban development projects. ${ }^{18}$ In contrast to Kotkin, who studies an urban and industrial structure that was built from scratch, our chapter looks at those frameworks of individual action that allowed for the persistence of traditional cultural practices and materials in urban environments in spite of the Soviet modernisation project.

14 Kalinovsky, Artemy: "Exploring 'Sovietness' in Local Context", in: Central Asian Affairs 4 (2017), p. 293-304; The essay is a book discussion of Abashin, Sergei: Sovetskii kishlak: mezhdu kolonializmom i modernizatsiei, Moscow: Novoe Literaturnoe Obozrenie 2015, p. 293-296.

15 Abashin, Sovetskii kishlak, p. 610.

16 Ibid.

17 See also Smith, Property of Communists.

18 Kotkin, Magnetic Mountain, p. 22. 
Our emphasis on persistence shows the limitations of a term that is commonly applied to activities of self-help home improvement in modern industrial societies: "Do-it-yourself" as a "culture" or even "movement" has been widely described as an inherently novel phenomenon, exported from the US to Western Europe in the 1950s and intimately tied to (and made possible by) the emergence of the affluent post-war society and the specific consumption culture and (male) leisure culture associated with it. ${ }^{19}$ In research on the Soviet Union, too, authors have established a qualitative change in the Soviet "repair society" following the "consumer turn" initiated by Khrushchev in the 1950s. ${ }^{20}$ The latter gave rise to an amateur "do-it-yourself" culture in the 1960s that has been interpreted in different ways - either as a partial subversion of Soviet state ideology through its emphasis on individualism ${ }^{21}$ or, in contrast, as firmly anchored in both the institutional and symbolic universe of the Soviet Union. ${ }^{22}$ When applied to the periphery of Soviet Union, however, the idea of a "do-it-yourself" culture arguably loses much of its explanatory power. The practices of building, maintaining and improving private homes in Soviet Samarkand that we describe in this chapter are not discursively framed as "modern" or "Soviet", nor are they manifestations of an individualist leisure culture within a collectivist system. On the contrary, they stand out for the references made in their interpretation to a pre-Soviet tradition of collective self-help.

\section{SOVIETNESS AS A MOSAIC: THE TRANSFORMATION OF SAMARKAND'S CITYSCAPE UNTIL 1960}

Our study focuses on the traditional courtyard house, the most prevalent type of housing in the cityscape of late-Soviet Samarkand. This prevalence was first a

19 On Germany see Voges, Jonathan: "Selbst ist der Mann": Do-it-yourself und Heimwerken in der Bundesrepublik Deutschland, Göttingen: Wallstein 2017, p. 10-12.

20 Golubev, Alexey/Smolyak, Olga: "Making Selves Through Making Things. Soviet Do-It-Yourself Culture and Practices of Late Soviet Subjectivation", in: Cahiers du monde russe 54 (2013), p. 517-541, here p. 526. See also Zinaida Vasilyevas' (yet unpublished) thesis project on Do-it-yourself and amateur culture in late and postSoviet Russia. For an interim report see Vasilyeva, Zinaida: "Do-It-Yourself Practices and Technical Knowledge in Late Soviet and Post-Soviet Russia", in: Tsantsa 17 (2012), p. 28-32.

21 Siegelbaum, Lewis H.: Cars for Comrades. The Life of the Soviet Automobile, Ithaca: Cornell University Press 2011, p. 243.

22 Golubev/Smolyak, "Making Selves Through Making Things", p. 521. 
result of the city's pre-Soviet architectural legacies. The Tsarist administration, after its conquest of Samarkand in 1868, had demolished the citadel and burned down parts of the bazaar as punishment for acts of resistance, ${ }^{23}$ but did not intervene in the centuries-old dense network of narrow alleyways and adobe brick courtyard houses in the old Islamic city. ${ }^{24}$ To build a new colonial city, the imperial administration instead focused on the old citadel and the area west of it. By the time of the October Revolution in 1917 Samarkand consisted of two parts of roughly the same size: the colonial city with its geometrical layout, around a series of radial axes, starting at the old citadel. This part of the city hosted administrative and European-style houses. Interestingly, many of these houses were also built of adobe bricks, sometimes coated with burnt bricks to reinforce them. ${ }^{25}$ The residents of these houses were merchants and families associated with the colonial administration, in total around 15,000 people of mostly European or Tartar origin. The majority of Samarkand's population of about 90,000 people, however, lived in the Old City. ${ }^{26}$

For the short period between 1924 and 1930 Samarkand became the capital of the newly founded Uzbek SSR, but it subsequently lost this status to Tashkent, the previous capital of the Turkestan Governorate and the Turkestan Autonomous Soviet Socialistic Republic, which existed between 1918 and 1924. The more industrialised, Russified and more Uzbek Tashkent seemed better suited for the Soviet vision of creating a socialist showcase city in Asia $^{27}$ and became the place where planning expertise for Uzbekistan and most construction resources were concentrated in the ensuing years. In Samarkand, the imprint of

23 Morrison, Alexander: Russian Rule in Samarkand 1868-1910. A Comparison with British India, Oxford: Oxford University Press 2008, p. 24-25.

24 According to the first all-Empire census in 1897 , by that time Samarkand was mostly inhabited by Tajik-speaking Muslims and Jewish groups (36,845 people) and 5,514 speakers of Uzbek. See Nikolaj, Trojnitskij; Pervaya vseobshaya perepis' naseleniya Rossijskoj Imperii, 1897 g., LXXXIII· Samarkandskaya oblast', St. Petersburg: izdanie Tsentral'nogo statisticheskogo komiteta ministerstva vnutrennikh del 1905, available online at https://www.prlib.ru/item/436672 (accessed 14.06.2019), p. 136137.

25 Nil'sen, Vladimir: U istokov sovremennogo gradostroitel'stva Uzbekistana XIX nachalo XX vekov, Tashkent: Izdatel'stvo literatury i iskusstva imeni Gafura Gulyama 1988, p. 106.

26 Giese, Ernst: "Transformation of Islamic Cities in Soviet Middle Asia into Socialist Cities", in: French, Richard A./Hamilton, F.E. Ian (eds.): The Socialist City. Spatial Structure and Urban Policy, Chichester et. al.: Wiley 1979, p. 145-166, here p. 151.

27 Stronski, Tashkent, p. 18. 
Stalinist rule on the cityscape remained modest except for the university and a number of dispersed residential and public buildings in the colonial part. ${ }^{28}$ The ambitious first general plan for Samarkand from 1937-38 that provided for the Old City to be demolished and replaced by a unified, planned city centre could not be realised owing to multiple constraints, meaning that the building stock of Samarkand remained almost unchanged until the early post-war years. ${ }^{29}$

With the outbreak of the Second World War, any efforts for the planned transformation of Samarkand's cities ground to a halt. All of a sudden, the city had to accommodate not only several factories that had been relocated from the frontlines in Europe, but also the biggest portion of the 160,000 evacuees who had been allocated to the Samarkand region (oblast) and thousands of deportees from all over the Soviet Union. ${ }^{30}$ In the absence of building materials, almost all of which were channelled into the war economy, the only way of accommodating the newcomers was the densification of existing housing stock. House owners all over the city were required to provide rooms to evacuees, especially in the colonial city backyards, which filled up with rudimentary structures, mostly simple shacks to accommodate whole families. These common yards (obšiy $d v o r$, where facilities like water taps and toilets were shared, were among the most visible manifestations of a massive housing shortage that lasted well into the $1950 \mathrm{~s}$, with an average of just $5.6 \mathrm{~m}^{2}$ per capita. ${ }^{31}$ Late Stalinist strategies to alleviate the housing crisis were generally piecemeal and incoherent, while the bulk of investments were directed to industry and architects remained focused on planning original buildings of neoclassical grandeur. ${ }^{32}$

Between 1951 and 1957, authorities began to address the housing crisis in a more focused and systematic way than before. ${ }^{33}$ Under Khrushchev the development of a mass housing programme gained traction and culminated in the decree of 1957, in which the leadership committed to providing separate and en-

28 Diener, Christa/Gangler Anette: Städte Usbekistans zwischen Tradition und Fortschritt. Städtische Transformationsprozesse der zentralasiatischen Städte Taschkent und Samarkand, Cottbus: BTU, Lehrstuhl Städtebau und Entwerfen, 2006, p. 210.

29 Ibid., p. 210.

30 Muminov, Ibragim: Istoriya Samarkanda v 2 tomakh. T. 2: Ot pobedy velikoj oktyabrskoj sotsialisticheskoj revolyutsii do nashikh dnej, Tashkent: Fan 1970, p. 232.

31 TsGARUz, f. 1619 (Central Department for Statistics/Tsentral'noe statisticheskoe upravlenie), op. 16, d. 4, 1. 25.

32 Smith, Property of Communists, p. 32-42.

33 Ibid., p. 21. 
closed living space for every family in the Soviet Union within a decade. ${ }^{34}$ Building in large quantities and adopting an approach based solely on "rationality" became the key motifs of a mass building programme that was now almost exclusively based on the prefabrication of standardised multi-storey apartment buildings, commonly known as khrushchevki. $^{35}$ As a result of the programme, per capita housing construction in the USSR was by far the highest in Europe between 1956 and 1963. It became known for improving the lives of tens of millions of citizens and for mass producing a newly uniform and undifferentiated Soviet cityscape. ${ }^{36}$ In Samarkand, however, it did so only at the city's Western margins. A first Kombinat for prefabrication of panels opened in 1958 as a precondition for a series of comparatively small housing projects to be built in the early 1960s. By the end of the 1960s Samarkand saw the completion of its first two micro-districts, ideal self-contained neighbourhoods that Soviet planners hoped would reconcile the maximisation of housing production, the need for separate family apartments and the communist idea of communal living. ${ }^{37}$

According to an inventory report by the city administration in $1951,95 \%$ of dwellings in Samarkand were made of adobe bricks $(70 \%)$ or timber-frame structures (with adobe filling) (25\%). ${ }^{38}$ The mass housing programme and construction of prefabricated apartment blocks from the 1960s onwards did change the proportions, but the share of houses built out of clay must have remained at least as high as the rate of privately owned houses. ${ }^{39}$ In the republic as a whole, the rate of privately owned houses remained between 35 and $40 \%$ until the end of the Soviet Union. ${ }^{40}$ This was not only because the old city centre remained largely unaffected by the programme, but also because the increasing volume of

34 Decree by the Central Committee of the Communist Party of the USSR from 03.07.1957. Available online at http://www.libussr.ru/doc_ussr/ussr_5213.htm (accessed 14.06.2019).

35 Smith, Property of Communists, p. 60.

36 Ibid., p. 4, 113.

37 State Archive of Samarkand Province/Samarkandskij Oblastnoj Gosudarstvennyj Arkhiv (SamOGA), f. 26 (Communal and Housing Commission of the City Executive Committee/Zhilishscno-kommunal'naya komissiya Gorispolkoma), op. 1, d. 2465. 11. $23-25$.

38 SamOGA f.26, op. 1, d. 1363, 1. 3

39 Because of prohibitive prices and restrictions on the number of burnt bricks that could be purchased in a year, clay remained the only available building material for individual houses.

40 Andrusz, Gregory D.: Housing and Urban Development in the USSR, London et. al.: Macmillan 1984, p. 291. 
new private housing space after 1950 was still largely built with clay. ${ }^{41}$ At the outskirts of the city and around the micro-districts, a thick belt of individually built adobe brick houses emerged. During the 1950s, this high degree of individual house building was not necessarily in conflict with the official Soviet housing policy. Historians have taken little note of the conspicuous policy of statebacked individual house construction that formed part of the administration's strategy to mitigate the post-war housing crisis and was a component of the mass-housing programme after $1957 .{ }^{42}$ Builders of private houses had access to specific loans, and handbooks with instructions for the self-help construction of houses circulated all over the Soviet Union. ${ }^{43}$

In Samarkand, the widespread practice of individual house building even continued after 1962, when an official degree introduced much stricter rules on the issuance of plots in urban areas of the Soviet Union. ${ }^{44}$ At the same time, the administration of Samarkand lacked effective control over building standards, regulations and the distribution of plots. Chaotic planning and disputes over jurisdiction, for example between the city administration and its neighbouring kolkhozes, meant that there was considerable scope for unregulated house building and extension. ${ }^{45}$ Like their counterparts in the Old City, owners of privately built houses in the new areas for private housing and in the outskirts of Samarkand largely maintained a high degree of agency in shaping the material and spatial configuration of their homes - albeit, of course, within the resource constraints of the Soviet command economy. They usually adapted standardised Soviet layouts to meet their specific needs, as will be shown in the next sections.

As a consequence of the described processes, Samarkand's cityscape in 1960 featured a patchwork of different types of private houses, including traditional courtyard houses in the old (pre-colonial) part of the city; residential houses built under Tsarist rule; standardised type houses that were erected on plots issued by the state during the Soviet period; traditional houses built in peri-urban areas on the margins between the city and the surrounding villages/collective farms; and various forms of illicitly built dwellings, often with shanty-town or slum-like character.

41 TsGARUz f. 1619, op. 16, d. 4, 1.35

42 Smith, Property of Communists, p. 36, 89.

43 Kuznecov, D./Skotnokov, V.: Posobie dlya individual'nogo zastrojshchika, Moscow: Izdatel'stvo ministerstva kommunal'nogo chozyajstva RSFSR 1958.

44 Decree of the CK CPU from 01.06.1962. Available online at http://www.libussr.ru/ doc_ussr/usr_5838.htm (accessed 14.06.2019).

45 Petrova, Mariya: Nah am Boden. Privater Hausbau zwischen Wohnungsnot und Landkonflikt im Samarkand der 1950er- und 60er-Jahre, Berlin: De Gruyter 2021. 
Despite its specific profile, Samarkand was not a rare exception within the USSR in terms of individual house building. In 1980, about 20 years after the start of mass housing campaign in 1957, the share of urban housing space in private hands in the Uzbek SSR remained at 40\%, down from 64\% in 1960. Figures in other Central Asian SSRs did not differ significantly. ${ }^{46}$ A calculation by Tulaganov et al. came to the result that as recently as in the early 2000 s, $60 \%$ $80 \%$ of Central Asian dwellings were made of soil. ${ }^{47}$

\section{SPACE-MAKING IN A COURTYARD HOUSE AND THE AMBIGUOUS TEMPORALITY OF ADOBE BRICKS}

The variety of different housing types in Soviet Samarkand, as described above, correlates with the multiple ethnic, linguistic and social backgrounds of the city's residents. ${ }^{48}$ In this chapter we concentrate on the courtyard house as a traditional local form that proved its persistence and flexibility throughout the Soviet period. Before examining the practices of building, maintaining and improving private houses in Samarkand it is important to understand the multitude of space-making processes that took place and went far beyond functional considerations. ${ }^{49}$ A study on the concept of "remont" in post-Soviet Tajikistan by Wladimir Sgibnev is instructive in this regard. In Tajikistan, remont, a term that describes all kinds of repair activities in Russian, is not only about mending something broken. Taking up Lefebvre's theory of "space production", he states that remont is rather a culturally embedded creative practice of creating spaces that were perceived as clean, representative and well-kept. ${ }^{50}$ In the case of courtyard houses these practices are narrowly connected with local Muslim and Ta-

46 Smith, Property of Communists.

47 Tulaganov, A. et al.: "Housing Construction with use of clay materials in Uzbekistan,” Kerpic - Living in Earthen Cities, Istanbul: Istanbul Technical University 2005.

48 When looking at the different types of homes it is helpful to differentiate between groups inhabiting Samarkand from the time before the Russian conquest and October Revolution and groups that moved or were moved into the region from Russia and other parts of the Soviet Union, including Russians, Armenians, Ukrainians, Koreans, Crimean Tatars and many others.

49 See Sgibnev, Wladimir: "Remont. Housing Adaptation as Meaningful Practice of Space Production in post-Soviet Tajikistan”, in: Europa Regional 22 (2014), p. 53-64, here p. 56.

50 Ibid., p. 55. 
jik/Uzbek ideas and ethics of family and household organisation. ${ }^{51}$ The form described below is to be understood as an ideal type as it was presented to us by different respondents. It could not always be achieved because of individual, financial or spatial constraints, but it would be aspired to by dwellers.

First, the house had to provide adequate space for different generations usually living together in a household: ideally, grandparents, the families of married sons (the youngest son was expected to stay with his parents permanently and other sons stayed until they had built their own houses) and unmarried daughters (married daughters moved to their husband's family) would have a separate space on their own which was sufficiently heated in winter. The number of stoves in the house was often a good indicator of the number of family "units" living in the house: "we had three stoves, one in our room, the other by grandma and grandpa, and the third was for the brother (who was married, authors)". ${ }^{52}$ From spring to autumn, most social life of the household would take place in the courtyard, where typically an aiwan provided for a shaded place and served as a rain shelter. An aiwan is the centrepiece of every Uzbek courtyard house, a mixture between a roofed pergola and a terrace on the side of one of the courtyard walls, carried by one or more columns. Functional spaces such as toilets, kitchens or washing rooms were sometimes integrated into the main building but were mostly located in separate buildings on the premises. Larger courtyards were often also used to grow fruit and vegetables or keep livestock on the plot, the size of which could range from $200 \mathrm{~m}^{2}$ in the city centre to $2,000 \mathrm{~m}^{2}$ in periurban areas. ${ }^{53}$

Equally important, if not more so, was the representative function of a house. In almost every house, one room had to provide enough space or was nearly exclusively reserved for receiving guests and for festivities. ${ }^{54}$ When deciding upon the layout of the house, the owner therefore had to find a balance between functionality and representativeness. Cultural norms required a strict separation between the well-maintained and decorated representative part of the house and an area for messy everyday activities which had to be concealed from the view of visitors - especially since these two areas were highly gendered. In households

51 For a comprehensive overview of current research on Central Asian families see Roche, Sophie (ed.): The Family in Central Asia: New Perspectives, Berlin: Klaus Schwarz 2017.

52 Interview 7, 25.09.2018, Samarkand, central mahalla.

53 Ibid.; Petrova, Nah am Boden.

54 See Interview 6, 22.09.2018, Samarkand, peri-urban area; also on Islamic festivities, for example the Kurbon celebration. 
following Islamic traditions, especially before and during the early Soviet rule, houses were often divided into "female" and "male" - in Uzbek ičkari ("inner") and taškari ("outer") realms. ${ }^{55}$ Other social conventions required periodic changes in the spatial arrangement of the house. While it was common, for example, for older sons to move out and establish their own household once they married, the youngest son had to stay on the premises with his family to take care of his parents, and hence needed separate rooms at the latest by the time of his marriage.

These requirements explain why only very few residents of the Old City were willing to move to the state-built micro-districts even if they received an apartment there. Although some of our respondents recall their admiration for the amenities provided in these apartments, none of them remembers actually wanting to live there. ${ }^{56}$ Like the apartments in the micro-districts, the spatial configuration of Soviet standardized designs (tipovoj proekt) for individual house building was largely incompatible with the spatial demands of an Uzbek family. These designs included standardised, detached single-family houses of two to four rooms with a square-shaped (c. $10 \times 10 \mathrm{~m})$ or rectangular (c. $8 \times 10 \mathrm{~m})$ layout. Once a family had managed to receive a plot, it had to request permission from the municipal planning authority to build a tipovoj proekt, or more often than not was assigned one. In comparison with compact type houses, the open layout of traditional courtyard houses allowed much more flexibility for setting up and (re)arranging the different spatial elements of an Uzbek or Tajik household at a relatively low cost.

As most rooms were accessible through the courtyard and not through corridors or hallways, additional rooms, extensions or small buildings could successively be added, moved or repurposed. ${ }^{57}$ Although the average living space available per capita in the Uzbek SSR (traditional and modern housing taken together) remained relatively low compared with the Soviet Union as a whole, ${ }^{58}$ the multifunctional use of the courtyard and relocation of many household activities into the courtyard during the warm season could partly compensate for

55 Voronina, V. L.: Narodnye traditsii architektury Uzbekistana, Moscow: Gosudarstvennoe izdatel'stvo arkhitektury i gradostroitel'stva 1951, p. 12.

56 Interview 6; Interview 7; Interview 2, 17.09.2018, Samarkand, central mahalla.

57 See Sgibnev, Remont, p. 58.

58 E.g. in 1975 the average living space per capita in Samarkand was $5.5 \mathrm{~m}^{2}$, SamOGA f. 1658 (Department of Planning and Architecture/Arkhitekturno-planirovochnoe upravlenie), op. 1, d. 220, 1.35. The sanitary norm was $9 \mathrm{~m}^{2}$ per capita. 
this scarcity of indoor living space. ${ }^{59}$ For these reasons, many house owners successively transformed their type houses into courtyard houses. This process can be traced not only in interviews with house owners but also in archival documents as people applied for permission to extend their houses or registered extensions retroactively.

This practice, of course, was contrary to the social engineering visions of Soviet architects and planners. Drawing on the sociocultural evolutionary theory of Marx and Engels they assumed that as a result of the increasing urbanisation and "societal development" of Central Asian societies, so-called "extended" families would automatically disappear - the majority of flats in multi-storey apartments were hence planned for the size of "European" nuclear families with 1-3 rooms. ${ }^{60}$ By the mid-1970s some voices were arguing for the recognition of traditional housing types in city planning and architecture, but attempts to implement these ideas went no further than the experimental stage. ${ }^{61}$

The extended family remained a widespread type of household in Samarkand throughout the entire Soviet period. ${ }^{62}$ Our observations suggest that there is a link between the persistence of social practices of space-making within these extended families and the temporality of adobe brick construction. The latter can be described as ambiguous: The long life of adobe brick construction as a technology that has not fundamentally changed for millennia in Central Asia contrasts with the impermanence of its materiality. ${ }^{63}$ The material is vulnerable to weather effects and necessitates a yearly routine of minor repairs after winter and a complete overhaul at least once per generation. ${ }^{64}$ One interviewee recalled that her house, passed down from her grandfather to her father, was in a bad state of disrepair because her father, a teacher, lacked the financial resources to

59 Rywkin, Michael: "Housing in Central Asia: Demography, Ownership, Tradition. The Uzbek Example", in: Grant, Steven A. (ed.): Soviet Housing and Urban Design, Washington, DC: U.S. Department of Housing and Urban Development 1980, p. 3943.

60 Rusanova, L. N.: "Demografiya i zhilishche. Po materialam issledovaniya naseleniya Samarkanda", in: Stroitel'stvo i arkhitektura Uzbekistana 3 (1968), p. 28-30.

61 Chebotareva, Z. N.: "V zashchitu plotnoj maloetazhnoj zastrojki", in: Stroitel'stvo i arkhitektura Uzbekistana 1 (1974), p. 28-32.

62 According to the SU-wide census in 1989 an average family in Uzbekistan consisted of 5.5 people. Families consisting of six people or more made up a share of $39 \%$. Boldyrev, V. A.: Itogi perepisi naseleniya SSSR: Naselenie SSSR. Po dannym vsesoyuznoj perepisi naseleniya 1989 g., Moscow: Finansy i statistika 1990, p. 32.

63 As an archaeologist that accompanied us on our field trip reassured us.

64 Interview 2; Interview 8, 26.09.2018, Samarkand, private residential area. 
maintain it properly ${ }^{65}$ Repair cycles were often defined by the social temporality of the courtyard house rather than functional considerations. Houses (or at least the parts that would be seen by visitors) had to be in shape for festive events that accompanied life cycle rituals such as circumcisions, weddings or funerals. ${ }^{66}$ The cost of renovation could actually account for a considerable part of the total expenses for such events. The material constitution of courtyard houses was hence in constant flux and intimately tied to the natural seasons and the life cycle of their inhabitants.

The recurring cycles of renovating, rebuilding and extending courtyard houses required construction materials that were affordable and readily available. While some industrially manufactured materials such as cement and gravel were available at affordable prices in state warehouses, most of the fundamental materials such as burnt bricks or wood were in constant shortage and reserved for government construction projects. In January 1967, for example, an order by the regional party committee prohibited the use of burnt bricks for building foundations, basement walls, retaining walls, etc. for individually built houses. ${ }^{67}$ Even if burnt bricks were available to buy, their costs were prohibitive. According to one respondent, in the 1970s the price for 1,000 bricks was around 120 rubles, which was the average monthly salary of an engineer. At the same time the number of bricks a person was allowed to buy in a year was limited to 2,000. As the construction of a house required between 12,000 and 16,000 bricks, a house made of fired bricks was almost impossible to build legally ${ }^{68}$ Adobe, in contrast, could be sourced from the ground, bypassing the formal Soviet command economy with its shortage of products and freely available professional labour. It was affordable as well $-1,000$ pieces would cost $14-15$ rubles. ${ }^{69}$

Moreover, when used in accordance with traditional architectural principles for building courtyard houses, adobe bricks offered good insulation properties. The specific orientation of the different elements of courtyard houses, their thick adobe brick walls, their ventilation system and their shady courtyards that usually featured a small garden or a water basin provided for a favourable microclimate and indoor temperature in the summer. While most urban planners in Rus-

65 Interview 2.

66 According to the depictions of two interviewees (Interview 2, Interview 6).

67 SamOGA f.1617 (Department for Construction and Architecture of the Provincial Executive Committee/Otdel po delam stroitel'stva i arkhitektury Oblispolkoma), op. 1, d. $233,1.3$.

68 Interview 3, 18.09.2018, Samarkand, private residential.

69 Ibid. 
sia dismissed the traditional mahallas as being unsanitary and inefficient, those visitors to Central Asia who actually entered courtyard houses could hardly ignore these advantages. Leonid Volynskii, a Russian traveller to Uzbekistan in 1961 who published his experiences in an article in the journal Novyi Mir, realised that in summer, the temperature in the traditional mud-brick homes in Tashkent was four or five degrees cooler than elsewhere in the city - including the newly built Soviet model district of Chilanzar, for which Volynskii had only harsh criticism. ${ }^{70}$ The labour intensiveness of clay and its low durability as material, however, required constant engagement with house construction, improvement and maintenance and thus brought about a particular form of social mobilisation.

\section{BUILDING IDENTITY WITH CLAY? SELF-HELP PRACTICES IN HOUSE CONSTRUCTION AND THEIR INTERPRETATIONS}

While adobe was abundantly available in the ground in Samarkand, using it for house construction was a time- and labour-intensive process. In the absence of a formal open market for the labour and services required, individual house building in Samarkand can be understood in terms of an elaborate strategy of selfhelp and labour mobilisation. We will now turn to the construction process in more detail. The timing of construction was largely determined by the seasons. The production of bricks was usually scheduled for May, June or July at the latest, when no more rain was to be expected, and the subsequent construction would be done in August-September. ${ }^{71}$ Adobe bricks need a special soil, so an experienced moulder would inspect the plot in search of a fitting layer of smooth loess soil, removing the upper metre of ground. ${ }^{72}$ To save transportation costs, clay for the bricks was usually extracted either from plot itself, thus at the same time excavating a hole for a foundation or basement, or from nearby.

Skilled workers for technically advanced tasks like foundation or carpeting were often invited or recruited from the pool of relatives. In general, most of the

70 See Stronski, Tashkent, p. 228.

71 Interview 6.

72 Samarkand is famous for having very thick (up to $25 \mathrm{~m}$ ) loess ground, which makes high-rise construction particularly difficult but provides perfect material conditions for earth construction (Interview 1, 19.06.2018, Samarkand, colonial city/microdistrict). 
knowledge associated with construction in the mahallas and peri-urban region was situated in the realm of traditional building practices rather than in the Soviet system of professional training. ${ }^{73}$ Most families would turn to masters of traditional building. One respondent recalled that her sister's husband was an usto - a master (in this context a foreman) who could advise them on quantities of building materials to be bought and supervise the construction: "My sister's husband was a technician, he told us how much cement and how many cars of gravel we needed to buy, then how many beams and bricks were needed. And the adobe bricks, we made them here in the yard." 74

Bricks were made by brigades of two or three. Often the moulders were young men - teenage schoolboys or university students who made bricks as a holiday job. ${ }^{75}$ They began by soaking the clay with water and then mixing and stamping it to remove as many air pockets as possible and create a consistent mass. The mass was then left to rest and be stamped again. Bricks were formed with a wooden mould and left to dry in direct sunlight, first on a plain surface and then piled up in small pyramids of three by three pieces. The bricks needed to dry for around 10-15 days to allow more air to escape. ${ }^{76}$ According to one of our respondents, a brigade could produce up to 1,000 bricks a day. The hole for the foundation was filled with stones, burnt bricks ${ }^{77}$ and, after the mid-1960s, when industrially produced cement became more easily available, also concrete. The bricks would be bound with liquid clay and for the plaster a mixture of clay and straw called saman was used. Another traditional technology widely used in Samarkand is called čub-kori - a Central Asian version of timber frame with mud-brick infill. ${ }^{78}$

The completion of a house within the period of just one summer was a rare exception. In most cases, people first built a foundation, one or two rooms and the roof, although the whole construction could last several years. One respondent recalled that when he was a schoolboy, his father started building an additional house (two rooms and a kitchen) on the opposite wall of the courtyard for his son's future family, apparently aware of a lengthy process to come. The construction went on to last for eight years. In the case of our respondent it was not

73 Fodde, Enrico: "Traditional Earthen Building Techniques in Central Asia", in: International Journal of Architectural Heritage 3 (2009), p. 145-168, here p. 152.

74 Interview 6.

75 Interview 3.

76 Interview 6.

77 Despite the restrictions some people reportedly did manage to obtain burnt bricks, but these practices were always connected with the informal realm of the Soviet economy.

78 Fodde, “Traditional Earthen Building Techniques", p. 149-151. 
money that was the limiting factor; instead it was the scarcity of industrially manufactured material: "We were building for so long, because we were waiting for the material. How it went: if you have obtained the beams - wait for boards. Once you've done the floor - wait for the laths. And so we did, room after room."

Whether building a new house or extending or rebuilding a house on an existing plot, self-help construction was usually not a one-time activity; it was a recurrent part of house owners' everyday lives over many years, often with the help of some of their neighbours and relatives. After all, building with clay was a labour-intensive process. As well as hiring day labourers on the informal labour market, the bulk of this manpower was recruited from the wider circle of relatives or neighbours. When referring to these practices of kinship or neighbourhood help, our Tajik and Uzbek respondents used the term hashar. A female respondent recalls the - highly gendered - process of collective building as follows: "We would buy wood and roofing slate, but concrete and all this - always by the method of hashar. We have a big family, we would invite brothers and nephews to come, prepare one big meal, and they would work." 80

Originally, the term hashar referred to a long-established practice of mobilising a large amount of (more or less) voluntary collective labour for the (re)construction and cleaning of irrigation canals, which were vital for the oasis and riverside villages and towns in Central Asia. ${ }^{81}$ Later it was also used for the collective construction and maintenance of public buildings, like mosques and private residential houses, as well as for seasonal work and activities associated with big festivities. ${ }^{82}$ Hashar had an important social meaning, as it was based on the principle of reciprocity whereby the exchange of obligations tightened social and informal institutions, thereby producing cultural identities. ${ }^{83}$ During the Soviet period, the term was ideologically supported and praised as a local form of socialist collectiveness, in particular in the context of individual housing construction. ${ }^{84}$ The idea of collective work for a common purpose fitted perfectly into the ideological framework of Soviet collective practices, such as subbotnik-

79 Interview 3.

80 Interview 6. See also Interview 7.

81 Obertreis, Imperial Desert Dreams, p. 31.

82 Sehring, Jennifer: The Politics of Water Institutional Reform in Neo-Patrimonial States: A Comparative Analysis of Kyrgyzstan and Tajikistan, Wiesbaden: Verlag für Sozialwissenschaften 2009, p. 70.

83 We are grateful to Sergei Abashin for this remark.

84 Razykov, A.: “Individual'nomu stroitel'stvu zhil'ya povsednevnoe vnimanie", in: Bloknot agitatora Tashkent 3 (1958), p. 11-18. 
days of "volunteer", unpaid work on Saturdays -, thereby providing an additional layer to its meaning. ${ }^{85}$

While practices of collective building of houses can be found all around the world, the complexity and persistence of hashar suggests that the mobilisation and subjectivation process they entail are specific to Soviet Central Asia. ${ }^{86}$ This observation becomes more evident when examining another metaphor that was voiced by different respondents in several variations such as "being close to the ground" (in Russian: blizko $k$ zemle) or "living on the ground" (žit' na zemle). The expression can generally refer to a down-to-earth person as well as an ability to master one's immediate material environment. People who were "close to the ground" or worked in professions that were "close to the ground", such as masons, carpenters, construction workers and the like, were considered to have the necessary skills to construct and renovate a house - a social categorisation. ${ }^{87}$ The expression would be also used to describe a desired living condition (to live on the earth, to have one's own plot) but as a means of cultural delimitation of one's own group. Asked if she ever considered moving to a Soviet microdistrict, one of our respondents, who defined herself as Tajik, answered: "No, it was never like this, we are not inclined to migrate, we live on the ground. I cannot imagine myself living on the 16th floor. The people don't have it, we don't have it in our blood, we have been sedentary tribes." 88

The obviously stylised self-image of the respondent is an example of the narratives that are present in identity discourses in today's Uzbekistan. ${ }^{89}$ They con-

85 The most known form of "voluntary-compulsory" collective work in Soviet Union was the subbotniki - state-organised collective activities for cleaning and tidying public places like streets and parks. In the context of Uzbek Republic the term hashar has been "translated" into the logic of collectivisation. For the use of hashar during the soviet period and its present connotation in Samarkand see Marteau d'Autry, Christilla: 'Vyjdem vse, kak odin! 'Allons-y tous comme un seul homme!' Ethnographie d'un hashar national dans un quartier de Samarkand, Ouzbékistan”, in: Cahiers d'Asie centrale 19/20 (2011), p. 279-301.

86 For other parts of the world see for example Holston's study on autoconstruction in Brazil. He argues that self-help construction of private houses can be understood as an "arena of [...] spatial, political, and symbolic mobilizations". Holston, James: "Autoconstruction in Working-Class Brazil”, in: Cultural Anthropology 6 (1991), p. 447465, here p. 447.

87 Petrova, Nah am Boden.

88 Interview 2.

89 The issue of Tajik and Uzbek self-images, the urban-sedentary dichotomies and corresponding narratives is part of the debate on Soviet and post-Soviet politics of national- 
trast this mode of housing with the idea of living high above the ground in the micro-districts. In this regard, answers from all our respondents living in the mahallas, Soviet-era private housing districts or semi-urban areas - notwithstanding their ethnic background - were similar. This reminds us to see private house construction as not solely a cultural but also a social phenomenon, one which aside from the desire to live "on the ground" required material and social means as well as practical skills. ${ }^{90}$ Those who had neither of the two would rather queue for flats in mikrorayons.

The discourse can also be traced in archival sources. The metaphor of being close to the ground, for example, was used by A. Kogan, the director of Samarkand's architectural and planning authority, in a critical memo on the prospects of housing construction in Samarkand in 1966. In the memo, he deplores the long-standing practice of poorly coordinated and fragmentary construction of individual houses that allowed for new mass housing projects only outside the former city limits and at the expense of transferred kolkhoz lands. Individual house construction in a city, he wrote, was "morally outdated", all the more so since it implied much higher costs for infrastructure provision than denser forms of housing. ${ }^{91}$ Kogan argued for a ban on individual house construction in Samarkand, but at the same time acknowledged that "the inclination of the local population to the ground" would pose a major obstacle for such an initiative. ${ }^{92}$

While the construction of individual houses is often about the exploitation and re-production of non-state spaces, it also appears to be an arena where different cultural and social identities are negotiated, especially notions of being Tajik/Uzbek and "Soviet". The question remains as to whether collective building practices can be generally interpreted as acts of "Soviet" collectivism or acts of (ethno)cultural self-affirmation within the Soviet state. Was this a contradiction at all? Following Abashin's argument about the mix of multiple sub-spaces and identities that often can be found in Central Asia, we suggest in our next sec-

ity and identity. Processes like national delimitation in the 1920s, the subsequent establishment of fixed ethnic categories, and nation-building after the breakdown of the Soviet Union have all inevitably left their mark on the identities of Central Asian inhabitants. For an in-depth discussion see Hirsh, Francine: Empire of Nations; Abashin, Sergei: Natsionalizmy v Srednej Azii v poiskakh identichnosti, St. Petersburg: Ateleya 2007.

90 Petrova, Nah am Boden.

91 "Morally outdated" is a Sovietism that can be translated in this context as "not state of the art any more".

92 SamOGA f. 1658, op. 2, d. 146, 1. 6-8. 
tion that both identities, at times, entered into a mutually stimulating relationship. ${ }^{93}$

\section{TRANSCENDING BOUNDARIES: COMPOSITE HOUSES, HYBRID MAHALLAS AND PRAGMATIC STATE OFFICIALS}

The (partly retrospective) interpretations of a collective house-building culture among both residents and the state bureaucracy seem to be very much structured along the dichotomies of tradition vs. modernity, low-rise vs. high-rise, urban sedentary vs. nomadic tradition, continuity vs. change, Soviet state bureaucracy vs. people. This was much less the case for actual practices on different levels and their material outcomes. On the contrary, when it comes to the more mundane level of everyday practice our study shows a high level of pragmatism and openness towards different tastes, needs and materials. While the adobe brick walls hardly changed at all, the houses' interiors bore witness to the interaction and mutual influence of notions of Sovietness and the patchwork of cultural identities that is characteristic for Samarkand - the material outcome can be described as hybrid.

In one interview, a woman who introduced herself as Tajik and lives in a mahalla in the Old City recalls an attitude she and her family internalised in the 1970s towards the traditional architectural elements of their aiwan. The aiwan of her family dated back to the end of the 19th century, when her great-grandfather, a wealthy merchant, lived in the house. It featured an elaborately carved wooden column and crossbar, and inside it was lavishly decorated with niches and traditional ornaments. Yet in the eyes of the family and their neighbours, "it meant poverty, for them it signified the past". ${ }^{44}$ The respondent recalled painting the aiwan together with her sister with a light blue paint that was mass-produced by a state company and had come to be used to paint doors and windows up to the remotest village in the Soviet Union. The painted aiwan would remain a visible signifier of Soviet material culture within the courtyard house until the late 1980s, providing a contrast to the adobe brick walls of the house's front part. ${ }^{95}$ Another interviewee in a different mahalla recalls his father covering the ceiling decoration and the carved columns with plywood "because it was practical for

93 Abashin, Sovetskii kishlak, p. 610.

94 Interview 2.

95 Interview 2. Traces of the blue paint were still visible at the time of the interview. 
craftsmen, for painters". ${ }^{96}$ In light of the precarious legal and material conditions for house improvement, pragmatism often prevailed over traditionalism. As for the roofs, few people had any qualms about letting go of clay roofing, which often leaked and required annual repair, when mass-produced fibre cement became a viable alternative for roof covering in the late 1960s and 1970s. ${ }^{97}$

Along with industrially manufactured materials and products, "European" tastes associated with Soviet material culture also began to influence ideas about interior design. While it was very common in Central Asia to put rugs on the floor for sitting and resting - a practice that also contributed to the freeing up of interior living space -, "European" seating furniture became an object of desire and a status symbol. The respondent recalled her envy towards their better-off neighbours who possessed a chandelier and a sofa - "things that our grandparents never had in their interior". ${ }^{98}$

The interior of houses and the appearance of mahallas became increasingly characterised by a materiality that can be interpreted as a hybrid between what were commonly understood as traditional and industrial technologies. The connection of the old mahallas in the centre to some of the networked urban infrastructures, with electricity taking off in the 1950s and gas arriving in the 1960s, ${ }^{99}$ was not only one of the first interventions by the state; it also revealed the boundaries of collective self-help building as it required expertise obtained in the Soviet vocational training system. When his mahalla was connected to the gas network in the 1970 s, a respondent recalls that:

"We would do everything by ourselves back at that time, we had no need for technicians. Technicians became necessary when you installed gas. [...] We had here a neighbour, he returned from his military service with a Russian wife, and their sons were technicians in our mahalla and built stoves in every house." 100

Many of the old cast-iron stoves that used coal or wood, however, would not be discarded but refurbished to work with gas. Rather than completely replacing older technologies, the arrival of networked infrastructures led to their modification or added another layer of technology.

\footnotetext{
96 Interview 9, 27.09.2018, Samarkand, central mahalla.

97 Interview 9, Interview 2.

98 Interview 2.

99 TsGARUz f. 1619 , op. 16 , d. 4, 1. 43 According to statistics, $29.1 \%$ of privately owned dwellings had electricity in 1950 . The share had increased to $83.4 \%$ by 1960 .

100 Interview 7.
} 
While Soviet urban planning and infrastructure development in the old city centre would alter the surface layers without fundamentally changing their material set-up, the new, private residential neighbourhoods that were built after 1950 were emerging as hybrids from the very beginning. In many cases, though not always, these areas started out as planned neighbourhoods with geometrical street grids, standardised type houses and mostly same-size plots. These areas were ethnically more diverse than the old mahallas in the centre, and instead of district mosques featured Soviet-type teahouses as meeting points and contained planned areas for public infrastructure like clubs, kindergartens and cinemas. Within their plots, however, many residents made use of a relatively high degree of freedom to gradually transform their type houses into courtyard houses and add characteristic elements of Central Asian houses such a pergola (aiwan) or a carpet-covered backless divan (takhta) in the yards - thus making the neighbourhoods increasingly resemble the central mahallas.

To do so, people initially benefited from a housing policy that increasingly tended to intertwine individual initiative and state capacity in the mid-1950s. Khrushchev's famous housing decree of 1957 explicitly lauded a method pioneered in Gorky (today Nizhny Novgorod) known as "peoples' construction", where brigades of non-construction workers built housing in their spare time in return for the guarantee of a new home. ${ }^{101}$ At times, Soviet officials displayed an astonishing pragmatism and ideological flexibility when it came to the interpretation of local traditions. In a report on the implementation of the central committee's housing policy in Uzbekistan in 1958, the author praised the translation of the Gorky method into hashar, using a number of successful examples as illustrations. ${ }^{102}$ In the early 1960s, however, Khrushchev's attitude towards individual construction and personal property in the housing economy changed, as the state capacity for construction had increased and the Soviet micro-district became a core element in the renewed vision of the communist future. In Samarkand, too, the city administration put a temporary halt to the expansion of the city at the expense of the surrounding kolkhozes and also stopped individual building. ${ }^{103}$

101 Smith, Property of Communists, p. 75 and 163; Harris, Steven E.: Communism on Tomorrow Street: Mass Housing and Everyday Life after Stalin, Washington, DC/Baltimore, MD: Woodrow Wilson Center Press/Johns Hopkins Univ. Press 2013, p. 154-162; Reid, Susan E.: "Makeshift Modernity: DIY, Craft and the Virtuous Homemaker in New Soviet Housing of the 1960s", in: International Journal for History, Culture and Modernity 2 (2014), p. 87-124, here p. 102.

102 Razykov, Individual'nomu stroitel'stvu, p. 17.

103 Petrova, Nah am Boden. 
Yet difficulties for the city administration in controlling individual house construction remained after 1960. Sanctions on illicit building activities were a rare exception. Amidst the chronic housing shortage, the city administration could hardly justify the removal of housing space without offering adequate alternatives. On the contrary, the ex-post legalisation of houses or extensions such as kitchens, garages or additional bedrooms was a frequent administrative routine in the work of the city executive councils. In most cases, bureaucrats displayed an astonishing pragmatism when it came such requests, as the following typical case shows:

"Comrade Chelebiev, when constructing his house, deviated from the approved plan and has built three rooms with total area of $52.20 \mathrm{~m}^{2}$ instead of $40 \mathrm{~m}^{2}$ and three additional kitchens. At the current moment he lives there with three families, ten people in total. [...] Considering the fact that the extension of the living area was made in order to provide adequate living conditions for ten people and the total area does not exceed the prescribed norm, the executive committee of the city council has decided to confirm the changes." 104

Whether on the level of the household, the mahalla or the cityscape, when it came to the more mundane questions of managing urban housing, the encounter of people, ideas and materials from both sides of the dichotomies mentioned at the beginning of this section can often be described in terms of coexistence or mutual influence rather than open conflict. The lack of open conflict, however, does not mean that people were not being subjected to state coercion. After all, although they were allowed to build their own houses, many were doing so because their previous dwellings - sometimes less than a kilometre away - had been demolished to make way for state construction projects. ${ }^{105}$

\section{CONCLUSIONS}

The starting point for this chapter was the persistence of both clay as a building material and the courtyard house as a type of housing in Samarkand throughout a period when the Soviet leadership under Khrushchev massively stepped up its efforts to bring its vision of socialist housing to fruition. Our account shows how, not only in the old mahallas in the city centre but also in newly emerging private residential areas, people maintained traditional collective practices of

104 SamOGA f. 1658, op. 2, d. 109, 1. 39.

105 Petrova, Nah am Boden. 
house building and improvement that offered a high degree of independence from the Soviet housing economy and the state's social engineering attempts.

By building with clay people could capitalise on existing traditional local knowledge and skills associated with this long-established technique. Given the widespread shortage of industrially produced construction material in a part of the Soviet Union that was generally less industrial than central Russia, it was a cost-effective (and in most cases the only) method to meet the requirements for the social production of space in housing. These processes of space-making were largely determined by the persistence of norms and conventions engrained in local traditions of household and family organisation. The physical characteristics of clay as a building material, in turn, induced and maintained social dynamics that differed markedly from those of other building materials, particularly those which were industrially manufactured. While it enabled people quite literally to build a house out of their own soil, it required the recurrent mobilisation of a relatively large amount of labour.

In this connection, hashar, a traditional Central Asian concept (as opposed to Soviet terms like subbotnik), appears as a strategy to mobilise a significant portion of the required labour among family and neighbours and thus enable a de facto withdrawal from the reach of urban planners. The deliberate reference to hashar, along with the projection of the general Russian metaphor of "being close to the ground" on the traditional urban culture of Samarkand, by both private house owners and city officials, set these practices of self-help construction against the Soviet urban modernisation agenda after the late 1950s. This conclusion, of course, needs to be made with due awareness of the construction aspects in oral history accounts, not least those which Hobsbawm has termed the "invention of tradition". ${ }^{106}$ Our observations add to a picture of housing as an arena where multiple cultural and social identities were negotiated. At a time when Khrushchev's mass housing campaign, with its focus on multi-storey, prefabricated concrete buildings, began to take off, building courtyard houses with clay inevitably became problematic for city planners and caused tensions.

While these tensions can certainly be identified in the prevalent discourse, we argue that there was a high degree of pragmatism in terms of both practices and policy. Although few people were willing to compromise on the courtyard

106 Hobsbawm, Eric J. (ed.): The Invention of Tradition, Cambridge: Cambridge University Press 1999; See also the discussion paper by Dadabaev, Timur: "The Role and Place of Oral History in Central Asian Studies", UI Papers 13, Elliot School of International Affairs, Washington University/CIDOB Center for International Affairs, Barcelona, 2014. 
house as a form of housing, they readily adopted industrially manufactured building materials when they became available, together with some "European" trends in interior design. Persistence, it appears, cannot be equated with stagnation. Faced with a chronic housing shortage that took much longer to mitigate than in other parts of the USSR, Soviet officials also displayed a high degree of pragmatism, for example when it came to the ex-post legalisation of individual buildings or their extensions.

Taking up Abashin's metaphor of a mosaic of Sovietness for areas of everyday life, we propose the concept of hybridity to describe the material outcomes of these processes of mutual influence. In the mundane courtyard house-turnedtype house of Samarkand, "Soviet" and "traditional" Central Asian elements merged into novel and original material assemblages. By focusing on the area of house construction, this chapter adds a piece to the jigsaw of the "Soviet experience" in Central Asia. 
